Volume 3 | Number 3 | March 2016
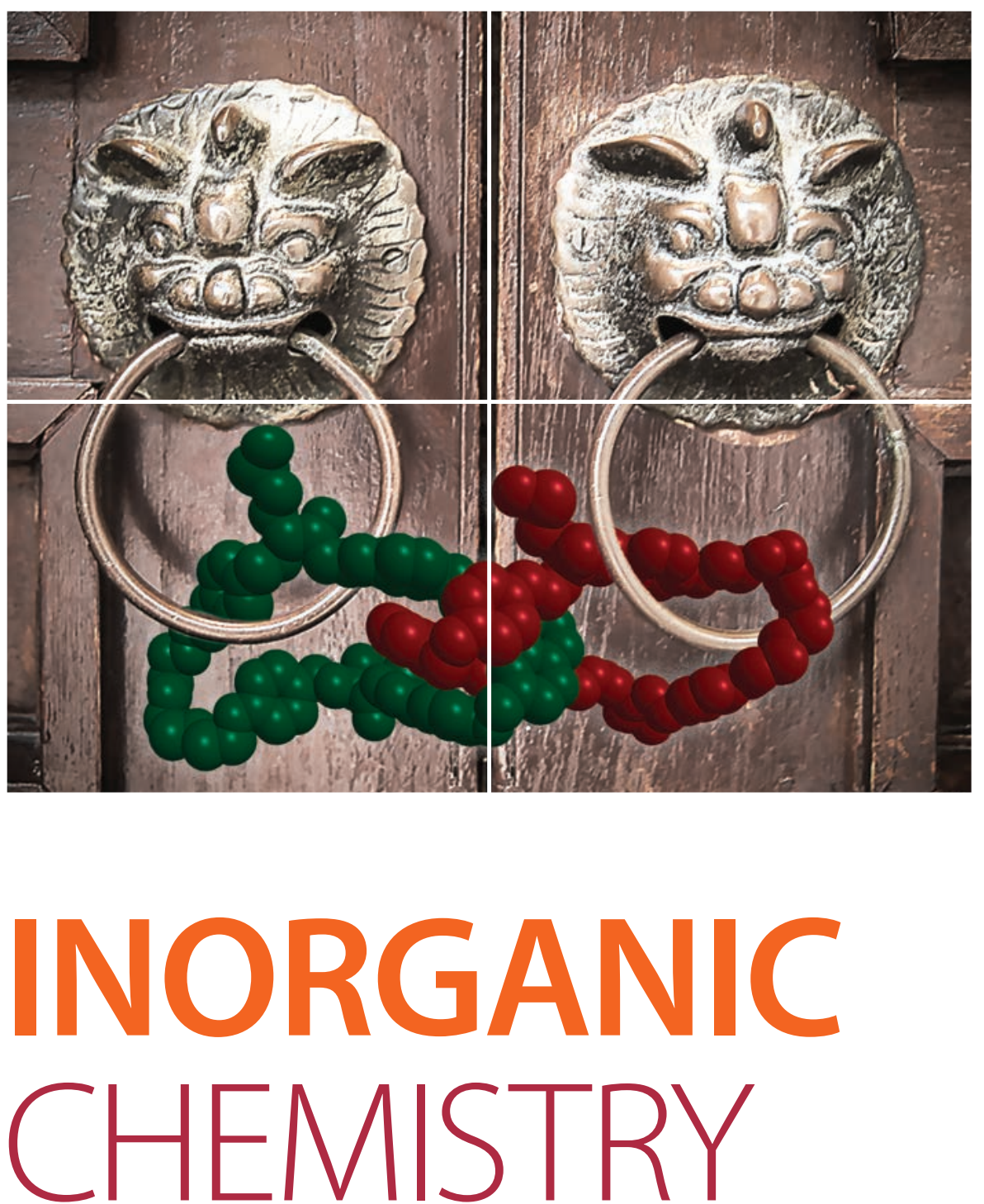

\title{
FRONTIERS
}




\title{
RESEARCH ARTICLE
}

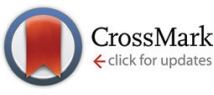

Cite this: Inorg. Chem. Front., 2016 3, 381

Received 28th October 2015 Accepted 26th December 2015

DOI: 10.1039/c5qi00219b

rsc.li/frontiers-inorganic

\section{Effects of hydroxyl group variations on a flavonoid backbone toward modulation of metal-free and metal-induced amyloid- $\beta$ aggregation $\dagger$}

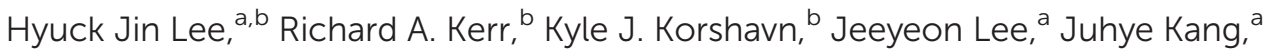 \\ Ayyalusamy Ramamoorthy, ${ }^{\star b, c}$ Brandon T. Ruotolo*b and Mi Hee Lim*a
}

Amyloid- $\beta$ (A $\beta$ ) and metal ions are suggested to be involved in the pathogenesis of Alzheimer's disease (AD). $\mathrm{Cu}(\|)$ and $\mathrm{Zn}(\|)$ can interact with $\mathrm{A} \beta$ and facilitate peptide aggregation producing toxic oligomeric peptide species. Additionally, redox-active metal-bound $A \beta$ is shown to generate reactive oxygen species (ROS). Although the interaction of metal ions with $A \beta$ and the reactivity of metal-associated $A \beta$ (metal-A $\beta$ ) are indicated, the relationship between metal $-A \beta$ and $A D$ etiology is still unclear. Some naturally occurring flavonoids capable of redirecting metal-A $\beta$ peptides into nontoxic, off-pathway $A \beta$ aggregates have been presented as valuable tools for elucidating the role of metal-A $\beta$ in $A D$. The structural moieties of the flavonoids responsible for their reactivity toward metal-A $\beta$ are not identified, however. To determine a structure-interaction-reactivity relationship between flavonoids and metal-free $A \beta$ or metal-A $\beta$, four flavonoids (morin, quercetin, galangin, and luteolin) were rationally selected based on structural variations (i.e., number and position of hydroxyl groups). These four flavonoids could noticeably modulate metal-A $\beta$ aggregation over metal-free analogue to different extents. Moreover, nuclear magnetic resonance (NMR) spectroscopy and mass spectrometry (MS) studies reveal that the direct interactions of the flavonoids with metal-free and/or metal-bound $A \beta$ are distinct. Overall, our studies demonstrate that alternation of the hydroxyl groups on the $B$ and $C$ rings of flavonoids (structure) could differentiate their metal/metal-free $A \beta /$ metal-A $\beta$ interactions (interaction) and subsequently direct their effects on metal-free $A \beta$ and metal$A \beta$ aggregation in vitro and $A \beta-/$ metal-A $\beta$-triggered toxicity in living cells (reactivity), suggesting a structure-interaction-reactivity relationship.
\end{abstract}

\section{Introduction}

Alzheimer's disease $(\mathrm{AD})$ is one of the severe incurable neurodegenerative diseases. ${ }^{1-8} \mathrm{AD}$ patients have symptoms of memory loss with being unable to conduct daily activities, eventually leading to death. ${ }^{1-8}$ This fatal disease can be characterized by shrinkage of the brain size and the presence of abnormally folded protein aggregates, such as amyloid- $\beta$ (A $\beta$ ) aggregates and neurofibrillary tangles, in the brain. ${ }^{3-10}$ In addition to that, it has been suggested that dyshomeostasis of metals (i.e., $\mathrm{Cu}$ and $\mathrm{Zn}$ ) is linked to the onset and progression of $\mathrm{AD} .^{2-15} \mathrm{Cu}(\mathrm{II})$ and $\mathrm{Zn}(\mathrm{II})$ are observed to bind to $\mathrm{A} \beta$ and facili-

\footnotetext{
${ }^{a}$ Department of Chemistry, Ulsan National Institute of Science and Technology (UNIST), Ulsan 44919, Korea.E-mail: mhlim@unist.ac.kr

${ }^{b}$ Department of Chemistry, University of Michigan, Ann Arbor, Michigan 48109, USA. E-mail:ramamoor@umich.edu,bruotolo@umich.edu

${ }^{c}$ Department of Biophysics, University of Michigan, Ann Arbor, Michigan 48109, USA $\dagger$ Electronic supplementary information (ESI) available: Fig. S1-S3 and Tables S1 and S2. See DOI: 10.1039/c5qi00219b
}

tate peptide aggregation generating oligomeric species, suggested to be toxic; copper-bound $\mathrm{A} \beta$ could produce reactive oxygen species (ROS) via Fenton-like reactions causing oxidative stress. $^{2-15}$ Although toxic $\mathrm{A} \beta$ conformations and oxidative stress induced by metal-associated $A \beta$ (metal- $A \beta$ ) are proposed to be involved in $\mathrm{AD}$ pathogenesis, ${ }^{3-15}$ the relationship between metal-A $\beta$ interaction/reactivity and $\mathrm{AD}$ development is not fully elucidated. To gain a better understanding of this relationship, chemical tools, capable of interacting directly with both metal ions and $\mathrm{A} \beta$ species and subsequently altering their reactivities (i.e., metal-A $\beta$ aggregation and metal-A $\beta$-induced toxicity), have been developed through a rational structure-based design strategy and screening of natural products, including flavonoids and curcumin. ${ }^{14-27}$

Among natural products, flavonoids have been of interest due to their anti-oxidant and anti-inflammation properties and potential usage for cancer, cardiovascular diseases, and dementia care. ${ }^{15,26-32}$ Flavonoids are polyphenolic compounds which are abundant in vegetables and fruits, especially berries. ${ }^{27-29,31,32}$ Recently, myricetin and (-)-epigallocatechin- 
3-gallate (EGCG) have been presented to interact with both metal ions and $A \beta$ peptides, confirmed by biochemical and biophysical techniques, as well as have the ability to control metal-A $\beta$ aggregation in vitro and alleviate toxicity triggered by metal-A $\beta$ in living cells. ${ }^{26,27}$ Although some flavonoids present their anti-amyloidogenic property, the structural moieties of flavonoids, responsible for such reactivity, are not identified. Multiple studies have previously reported potential metal chelation sites of numerous flavonoids and their influence on metal-free $A \beta$ aggregation. ${ }^{26,27,30-40}$ Detailed investigations of the interaction between $A \beta$ and flavonoids and their effects on metal-free and metal-induced $\mathrm{A} \beta$ aggregation have been rarely reported, however. ${ }^{26,27}$ In particular, a structure-interactionreactivity relationship between flavonoids and metal-free $A \beta$ or metal-bound $\mathrm{A} \beta$ has not been established.

Herein, we present the interaction and reactivity with metal-free $\mathrm{A} \beta$ and metal-A $\beta$ of four flavonoids (morin, quercetin, galangin, luteolin; Fig. 1), along with their metal chelation property. These four flavonoids were rationally selected based on structural variations (i.e., number and position of hydroxyl groups on a flavonoid backbone). Morin, quercetin, and galangin (Fig. 1) have different numbers of hydroxyl groups on the $\mathrm{B}$ ring. Luteolin has the same catechol group on the B ring as quercetin, while it does not have a hydroxyl group on the C ring (C3 position; 3-OH; Fig. 1). Through our studies, the selected flavonoids are observed to modulate both aggregation and toxicity of metal-free $\mathrm{A} \beta$ and/or metal- $\mathrm{A} \beta$ in vitro and in living cells, respectively, to different extents. Hydroxyl groups on the $\mathrm{B}$ ring might have a significant effect on the aggregation pathways of metal-A $\beta$ over metal-free $A \beta$, as well as the $3-\mathrm{OH}$ functionality might also play a role in the interaction with metal ions and $\mathrm{A} \beta$ peptides. Moreover, our biophysical

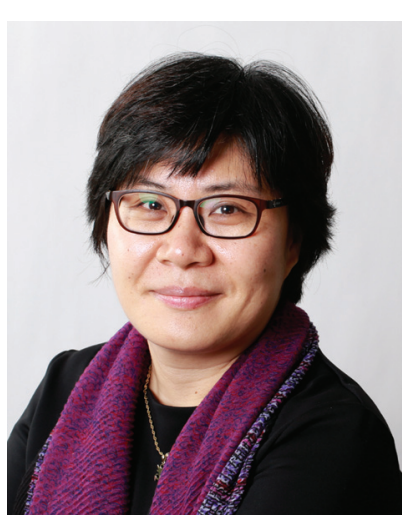

Mi Hee Lim
Mi Hee Lim is an Associate Professor in the Department of Chemistry at the Ulsan Institute of Science and Technology (UNIST), Ulsan, Korea. She obtained her MSc degree under Professor Wonwoo Nam at Ewha Womans University, Seoul, Korea, and a PhD degree under the supervision of Professor Stephen J. Lippard at MIT. She was a TRDRP postdoctoral fellow with Professor Jacqueline K. Barton at Caltech. In the summer of 2008, she began her independent work as an Assistant Professor of Chemistry and Research Assistant Professor in the Life Sciences Institute at the University of Michigan, Ann Arbor, MI, USA. In the fall of 2013, Dr Lim joined UNIST as an Associate Professor with tenure. Her current research focuses on elucidating the roles of metals, proteins, and reactive oxygen species in human neurodegenerative diseases.
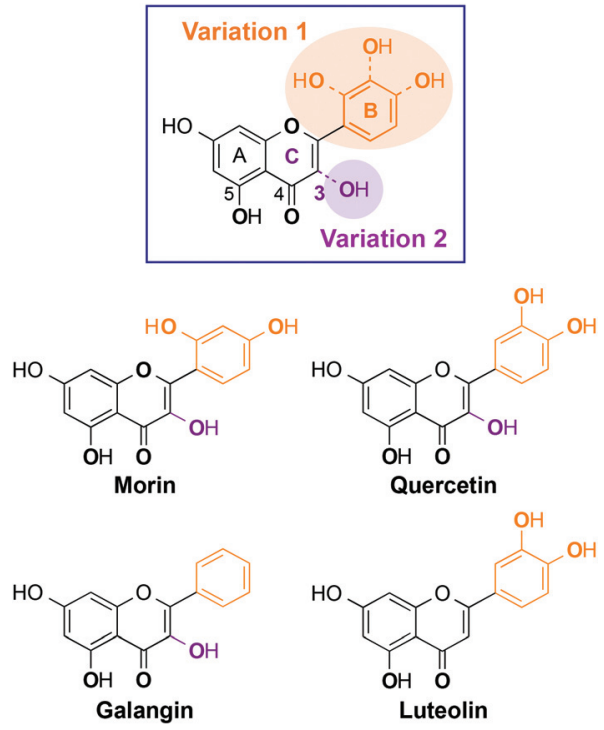

Fig. 1 Structures of the flavonoids studied in this work. Morin: 2-(2,4dihydroxyphenyl)-3,5,7-trihydroxy-4H-chromen-4-one; quercetin: 2(3,4-dihydroxyphenyl)-3,5,7-trihydroxy-4H-chromen-4-one; galangin: 3,5,7-trihydroxy-2-phenyl-4H-chromen-4-one; luteolin: 2-(3,4-dihydroxyphenyl)-5,7-dihydroxy-4H-chromen-4-one. The structural variations of the $B$ and $C$ rings on a flavonoid backbone are highlighted in orange and purple. Potential donor atoms for metal interaction are in bold.

analyses employing 2D nuclear magnetic resonance (NMR) spectroscopy and ion mobility-mass spectrometry (IM-MS) also demonstrate the interactions of our selected flavonoids, composed of different numbers and positions of hydroxyl substituents, with metal-free $A \beta$ and/or metal-bound $A \beta$ to distinct degrees. Taken together, our studies demonstrate a structureinteraction-reactivity relationship between the flavonoids and metal-A $\beta$ (over metal-free $\mathrm{A} \beta$ ), which could advance our knowledge of developing chemical tools for targeting and regulating metal-A $\beta$ found in $\mathrm{AD}$.

\section{Experimental}

\section{Materials and methods}

All reagents were purchased from commercial suppliers and used as received unless otherwise stated. Morin and quercetin were purchased from Abcam (Cambridge, MA, USA); galangin and luteolin were acquired from Santa Cruz Biotechnology (Dallas, TX, USA) and Alfa Aesar (Ward Hill, MA, USA), respectively. The flavonoids were used without further purification. Trace metal contamination was removed from buffers and solutions used for $A \beta$ experiments by treating with Chelex (SigmaAldrich, St. Louis, MO, USA) overnight. A $\beta_{40}$ (DAEFRHDSGYEVHHQKLVFFAEDVGSNKGAIIGLMVGGVV) and $\mathrm{A} \beta_{42}$ (DAEFRHDSGYEVHHQKLVFFAEDVGSNKGAIIGLMVGGVVIA) were obtained from Anaspec (Fremont, CA, USA) and Anygen (Nam-myun, Jangseong-gun, Korea). Double distilled $\mathrm{H}_{2} \mathrm{O}$ $\left(\mathrm{ddH}_{2} \mathrm{O}\right)$ was obtained from a Milli-Q Direct 16 system (Merck 
KGaA, Darmstadt, Germany). Optical spectra for metal binding studies were recorded on an Agilent 8453 UV-Visible (UV-Vis) spectrophotometer. Transmission electron microscopy (TEM) images were collected on a JEOL JEM-2100 transmission electron microscope (UNIST Central Research Facilities, Ulsan, Korea). A SpectraMax M5 microplate reader (Molecular Devices, Sunnyvale, CA, USA) was used to measure the absorbance for the MTT assay [MTT = 3-(4,5-dimethylthiazol-2-yl)2,5-diphenyl-tetrazolium bromide].

\section{Amyloid- $\beta$ (Aß) peptide experiments}

$\mathrm{A} \beta$ experiments were conducted according to previously published methods. ${ }^{16-27} \mathrm{~A} \beta$ peptides were dissolved with ammonium hydroxide $\left(\mathrm{NH}_{4} \mathrm{OH}, 1 \% \mathrm{v} / \mathrm{v}\right.$, aq.), aliquoted, lyophilized, and stored at $-80{ }^{\circ} \mathrm{C}$. A stock solution ( $\left.c a .200 \mu \mathrm{M}\right)$ was prepared by re-dissolving $\mathrm{A} \beta$ with $\mathrm{NH}_{4} \mathrm{OH}(1 \% \mathrm{w} / \mathrm{v}$, aq., $10 \mu \mathrm{L})$ followed by dilution with $\mathrm{dd}_{2} \mathrm{O}$. The concentration of the solution was determined by measuring the absorbance of the solution at $280 \mathrm{~nm}\left(\varepsilon=1450 \mathrm{M}^{-1} \mathrm{~cm}^{-1}\right.$ for $\mathrm{A} \beta_{40} ; \varepsilon=1490 \mathrm{M}^{-1}$ $\mathrm{cm}^{-1}$ for $\left.\mathrm{A} \beta_{42}\right)$. Buffered solutions [20 mM HEPES (4-(2hydroxyethyl)-1-piperazineethanesulfonic acid), pH 6.6 or 7.4, $150 \mathrm{mM} \mathrm{NaCl}$ ] were used for both inhibition and disaggregation studies [ $\mathrm{pH} 6.6$ for $\mathrm{Cu}(\mathrm{II})$ samples; $\mathrm{pH} 7.4$ for metal-free and $\mathrm{Zn}$ (II) samples]. For the inhibition experiments, $\mathrm{A} \beta(25 \mu \mathrm{M})$ was first treated with or without a metal chloride salt $\left(\mathrm{CuCl}_{2}\right.$ or $\mathrm{ZnCl}_{2} ; 25 \mu \mathrm{M}$ ) for 2 min followed by addition of morin, quercetin, galangin, or luteolin $(50 \mu \mathrm{M} ; 1 \% \mathrm{v} / \mathrm{v}$ final DMSO concentration). The resulting samples were incubated at $37^{\circ} \mathrm{C}$ for $24 \mathrm{~h}$ with constant agitation. For the disaggregation experiments, $A \beta$ in the absence or presence of a metal chloride salt $\left(\mathrm{CuCl}_{2}\right.$ or $\left.\mathrm{ZnCl}_{2}\right)$ was initially incubated at $37{ }^{\circ} \mathrm{C}$ for $24 \mathrm{~h}$ with steady agitation. The compound was added into the resulting solution afterward followed by an additional $24 \mathrm{~h}$ of incubation at $37^{\circ} \mathrm{C}$ with constant agitation.

\section{Gel electrophoresis with Western blotting}

The resultant $\mathrm{A} \beta$ species from both inhibition and disaggregation experiments were analyzed by gel electrophoresis followed by Western blotting (gel/Western blot) using an anti-A $\beta$ antibody (6E10). ${ }^{16-27}$ Each sample $(10 \mu \mathrm{L},[\mathrm{A} \beta]=25 \mu \mathrm{M})$ was separated using a $10-20 \%$ gradient Tris-tricine gel (Invitrogen, Grand Island, NY, USA). The gel was transferred to a nitrocellulose membrane and blocked with a bovine serum albumin (BSA) solution ( $3 \% \mathrm{w} / \mathrm{v}$; Sigma, St. Louis, MO, USA) in Trisbuffered saline (TBS; Fisher, Pittsburgh, PA, USA) containing $0.1 \%$ Tween-20 (TBS-T; Sigma-Aldrich) for $3 \mathrm{~h}$ at room temperature. The membrane was treated with the A $\beta$ monoclonal antibody (6E10; Covance, Princeton, NJ, USA; 1 : 2000; BSA, 2\% $\mathrm{w} / \mathrm{v}$, in TBS-T) overnight at $4{ }^{\circ} \mathrm{C}$ and then probed with a horseradish peroxidase-conjugated goat anti-mouse secondary antibody (1:5000; Cayman Chemical, Ann Arbor, MI, USA) in 2\% BSA in TBS-T solution for $1 \mathrm{~h}$ at room temperature. A $\beta$ species were visualized using a Thermo Scientific Supersignal West Pico Chemiluminescent (ECL) substrate (Rockford, IL, USA) or a self-made ECL solution (2.5 mM luminol, $0.20 \mathrm{mM}$-coumaric acid, and $0.018 \% \mathrm{H}_{2} \mathrm{O}_{2}$ in $100 \mathrm{mM}$ Tris, $\mathrm{pH}$ 8.6). Note that the gel analysis presented herein is qualitative due to the properties of the resulting $\mathrm{A} \beta$ species.

\section{Transmission electron microscopy (TEM)}

Samples for TEM were prepared following previously reported methods. ${ }^{16-27}$ Glow discharged grids (Formar/Carbon 300mesh; Electron Microscopy Sciences, Hatfield, PA, USA) were treated with samples from either inhibition or disaggregation experiments $(5 \mu \mathrm{L})$ for $2 \mathrm{~min}$ at room temperature. The excess sample was removed with filter paper and the grids were washed with $\mathrm{ddH}_{2} \mathrm{O}$ three times. Each grid was stained with

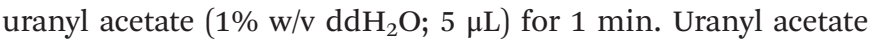
was blotted off and grids were dried for $20 \mathrm{~min}$ at room temperature. Images of samples were taken by using a JEOL JEM-2100 transmission electron microscope (200 kV, 25 000× magnification).

\section{Copper binding studies}

$\mathrm{Cu}$ (II) interaction of flavonoids was determined by UV-Vis based on previously reported procedures. ${ }^{25-27}$ A solution of ligand $(25 \mu \mathrm{M}$ in $20 \mathrm{mM}$ HEPES, $\mathrm{pH} 7.4,150 \mathrm{mM} \mathrm{NaCl})$ was prepared, treated with $0.5,1$, and/or 2 equiv. of $\mathrm{CuCl}_{2}$, and incubated at room temperature for $10 \mathrm{~min}$. In order to verify if $\mathrm{Cu}$ (II) binding to the ligand occurs in the presence of $\mathrm{A} \beta_{40}$, optical studies were performed on the samples of $\mathrm{A} \beta_{40}(25 \mu \mathrm{M})$ preincubated with 0 or 1 equiv. of $\mathrm{CuCl}_{2}$ in the absence and presence of flavonoids $(25 \mu \mathrm{M})$. The optical spectra of the resulting solutions were measured after $10 \mathrm{~min}$ incubation.

\section{D nuclear magnetic resonance (NMR) spectroscopy}

The interaction between ligands and ${ }^{15} \mathrm{~N}$-labeled $\mathrm{A} \beta_{40}$ was monitored by $2 \mathrm{D}$ band-Selective Optimized Flip-Angle Short Transient Heteronuclear Multiple Quantum Coherence (SOFAST-HMQC) at $10{ }^{\circ} \mathrm{C} .{ }^{41}$ Uniformly ${ }^{15} \mathrm{~N}$-labeled $\mathrm{A} \beta_{40}$ (rPeptide, Bogart, GA, USA) was dissolved in $1 \% \mathrm{NH}_{4} \mathrm{OH}$, aliquoted, and lyophilized. The peptide ( $80 \mu \mathrm{M}$ peptide) was redissolved in $3 \mu \mathrm{L}$ of DMSO- $d_{6}$ (Cambridge Isotope, Tewksbury, MA, USA) and diluted in PBS (20 mM $\mathrm{PO}_{4}, \mathrm{pH} 7.4,50 \mathrm{mM}$ $\mathrm{NaCl} ; 7 \% \mathrm{v} / \mathrm{v} \mathrm{D}_{2} \mathrm{O}$ ). Compounds were titrated into the peptide solution from a $50 \mathrm{mM}$ stock solution in DMSO- $d_{6}$ up to 10 equiv. $(800 \mu \mathrm{M})$. Spectra were acquired using 64 complex $t_{1}$ points and a $0.1 \mathrm{~s}$ recycle delay on a Bruker Avance $600 \mathrm{MHz}$ spectrometer equipped with a cryoprobe. $2 \mathrm{D}$ data were processed using TOPSPIN 2.1 (from Bruker) and assignment was performed using SPARKY 3.1134 using published assignments for $\mathrm{A} \beta_{40}$ as a guide. ${ }^{42-44}$ Chemical shift perturbation (CSP) was calculated by using the following equation (eqn (1)):

$$
\Delta \delta_{\mathrm{NH}}=\sqrt{\Delta \delta \mathrm{H}^{2}+\left(\frac{\Delta \delta \mathrm{N}}{5}\right)^{2}}
$$

\section{Ion mobility-mass spectrometry}

All ion mobility-mass spectrometry (IM-MS) experiments were carried out on a Synapt G2 (Waters, Milford, MA, USA). ${ }^{45,46}$ 
Samples were ionized using a nano-electrospray (nESI) source operated in positive ion mode. MS instrumentation was operated at a backing pressure of 2.7 mbar and a sample cone voltage of $40 \mathrm{~V}$. For peptide-derivative-metal ligation studies, aliquots of $\mathrm{A} \beta_{40}$ peptides (final concentration, $20 \mu \mathrm{M}$ ) were sonicated for $5 \mathrm{sec}$ prior to preincubation with or without a source of $\mathrm{Cu}$ (II) (copper(II) acetate, $20 \mu \mathrm{M}$ ) at $37^{\circ} \mathrm{C}$ for $10 \mathrm{~min}$. After preincubation, either the flavonoid of interest was added (final concentrations, 20, 40, 80, and $120 \mu \mathrm{M}$ ) and incubated at $37^{\circ} \mathrm{C}$ for $30 \mathrm{~min}$ prior to analysis, or a similar flavonoid-free dilution protocol was used as a control. Solution conditions were $100 \mathrm{mM}$ ammonium acetate ( $\mathrm{pH}$ 7.5) with 1\% v/v DMSO. For control purposes, all data are compared against incubations of $\mathrm{A} \beta_{40}$ peptides with EGCG under the same conditions. Collision cross-section (CCS) measurements were externally calibrated using a database of known values in helium using values for proteins that bracket the likely CCS and ion mobility values of the unknown ions. ${ }^{47,48}$ CCS values are the mean average of five replicates, with errors reported as the least squares product. This least squares analysis combines inherent calibrant error from drift tube measurements $(3 \%),{ }^{48}$ calibration curve error, and twice the replicate standard deviation error. The dissociation constants $\left(K_{\mathrm{d}} \mathrm{s}\right)$ for $\mathrm{A} \beta$-flavonoid complexes were calculated using the total ion count extracted from the peak of interest at its full width half maximum using methods previously described. ${ }^{49,50}$ All other conditions are consistent with previously reported procedures. $^{16}$

\section{Cytotoxicity studies}

The human neuroblastoma SH-SY5Y cell line was purchased from the American Type Culture Collection (ATCC, Manassas, VA, USA). Cells were maintained in media containing 1:1 Minimum Essential Media (MEM; GIBCO, Grand Island, NY, USA) and Ham's F12 K Kaighn's Modification Media (F12 K; Gibco), $10 \%$ (v/v) fetal bovine serum (FBS; Sigma), and 1\% $(\mathrm{v} / \mathrm{v})$ penicillin (Gibco). The cells were grown and maintained at $37^{\circ} \mathrm{C}$ under a humidified atmosphere with $5 \% \mathrm{CO}_{2}$. Cell viability with treatment of $\mathrm{A} \beta$ and/or flavonoids was determined using the MTT assay (Sigma) as previously reported. ${ }^{21-24}$ SH-SY5Y cells were seeded in a 96 well plate (15000 cells in $100 \mu \mathrm{L}$ per well) and treated with $\mathrm{A} \beta(10 \mu \mathrm{M})$ and/or flavonoids (10 $\mu \mathrm{M}$; final $1 \% \mathrm{v} / \mathrm{v}$ DMSO). After $24 \mathrm{~h}$ of incubation at $37^{\circ} \mathrm{C}$, MTT (25 $\mu$ l of $5 \mathrm{mg} \mathrm{mL}^{-1}$ in phosphate buffered saline, PBS, pH 7.4; Gibco) was added to each well and the plates were incubated for $4 \mathrm{~h}$ at $37^{\circ} \mathrm{C}$. Formazan produced by the cells was dissolved overnight at room temperature by the addition of a solubilization buffer $(100 \mu \mathrm{L})$ containing $N, N$-dimethylformamide (DMF; 50\% v/v, aq.) and sodium dodecyl sulfate $(\mathrm{SDS} ; 20 \% \mathrm{w} / \mathrm{v})$. The absorbance $\left(\mathrm{A}_{600}\right)$ was measured on a microplate reader. Cell viability was determined relative to cells containing an equivalent amount of DMSO $(1 \% \mathrm{v} / \mathrm{v})$. Error bars were calculated as standard errors of four independent experiments.

\section{Results and discussion}

Rational selection of flavonoids for investigating a structureinteraction-reactivity relationship with metal-free $A \beta$ and metal-A $\beta$

Some naturally occurring flavonoids are shown to target metal- $\mathrm{A} \beta_{40}$, modulate metal- $\mathrm{A} \beta_{40}$ aggregation in vitro, and diminish cytotoxicity induced by metal- $\mathrm{A} \beta_{40} ;{ }^{26,27}$ however, the structural moieties responsible for such interactions and reactivities with metal-A $\beta_{40}$ are not fully identified. To obtain a better understanding of the structure-interaction-reactivity relationship between flavonoids and metal-free $\mathrm{A} \beta$ and/or metal-A $\beta$, four different flavonoids (morin, quercetin, galangin, and luteolin; Fig. 1) were rationally selected with the variations of hydroxyl groups on their basic backbone. These flavonoids, composed of different numbers or positions of hydroxyl groups on the $\mathrm{B}$ and $\mathrm{C}$ rings (Fig. 1), toward metalfree $A \beta$ and metal-A employing two major isoforms of $A \beta$ $\left(\mathrm{A} \beta_{40}\right.$ and $\left.\mathrm{A} \beta_{42}\right)$ found in the $\mathrm{AD}$-affected brain, ${ }^{3,5,8}$ were investigated to determine which structural portions are important for their influence on $A \beta$ aggregation pathways and toxicity. In particular, it could be valuable to illuminate whether and how structural variations of the flavonoids affect their interaction and reactivity with two $A \beta$ isoforms $\left(A \beta_{40}\right.$ and $\left.A \beta_{42}\right)$, since these two $A \beta$ peptides have different aggregation properties: (i) $A \beta_{42}$ is more prone to aggregate than $A \beta_{40}{ }^{2,5-10}$ (ii) $A \beta_{42}$ is shown to form pentamers or hexamers as paranuclei while $A \beta_{40}$ does not aggregate from monomers to fibrils through the generation of paranuclei. ${ }^{51}$ As depicted in Fig. 1, morin, quercetin, and galangin were chosen for our studies to verify whether the different number of hydroxyl groups on the $\mathrm{B}$ ring, with the same structure as the $\mathrm{A}$ and $\mathrm{C}$ rings, could alter the reactivity toward metal-free $\mathrm{A} \beta$ and metal-A $\beta$. In addition, a hydroxyl group on the $\mathrm{C}$ ring at the $3 \mathrm{C}$ position (3-OH group; Fig. 1) with the most acidic proton is shown to be involved in metal binding; ${ }^{36,51,52}$ hence, we also included luteolin (Fig. 1), for our investigations, which has a catechol group on the B ring as quercetin but does not contain the $3-\mathrm{OH}$ moiety.

\section{Effects of morin, quercetin, galangin, and luteolin on metal- free $A \beta$ and metal-induced $A \beta$ aggregation in vitro}

To identify how the structural difference of flavonoids affects metal-free $\mathrm{A} \beta$ and metal-A $\beta$ aggregation, two different inhibition and disaggregation experiments were conducted. For inhibition experiments (Fig. 2 and 3, left), freshly dissolved $\mathrm{A} \beta$ $(25 \mu \mathrm{M})$ with or without $\mathrm{CuCl}_{2}$ or $\mathrm{ZnCl}_{2}(25 \mu \mathrm{M})$ was treated with flavonoids $(50 \mu \mathrm{M})$ for $24 \mathrm{~h}$. In the case of disaggregation experiments (Fig. 2 and 3, right), the preformed aggregates, generated by incubation of fresh $\mathrm{A} \beta(25 \mu \mathrm{M})$ for $24 \mathrm{~h}$, with or without $\mathrm{CuCl}_{2}$ or $\mathrm{ZnCl}_{2}(25 \mu \mathrm{M})$, were treated with flavonoids $(50 \mu \mathrm{M})$ for additional $24 \mathrm{~h}$. Size distributions and morphological changes of the resulting $A \beta$ species from both experiments were observed by gel electrophoresis followed by Western blotting (gel/Western blot) with an anti-A $\beta$ antibody (6E10) and TEM, respectively. 
Inhibition Experiment

Fresh $\mathbf{A} \beta_{40} \pm \underset{\substack{\mathrm{Or} \\ \mathrm{ZnCl}}}{\mathrm{CuCl}_{2}} \underset{2 \mathrm{~min}, \mathrm{RT}}{\longrightarrow} \frac{\text { Flavonoids }}{37^{\circ} \mathrm{C}, 24 \mathrm{~h} \text {, Agitation }} \longrightarrow \begin{gathered}\mathbf{A} \beta_{40} \\ \text { Species }\end{gathered}$
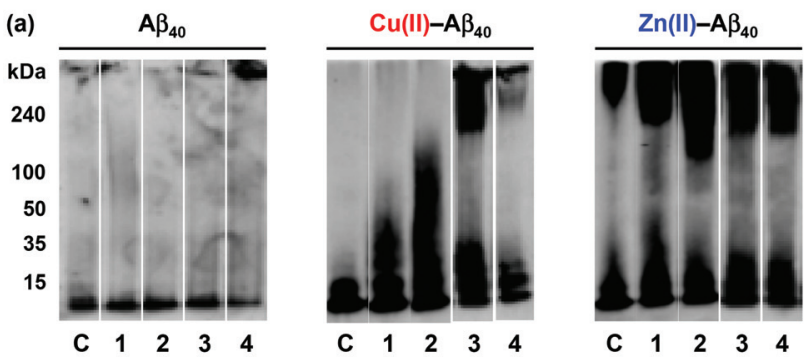

(b)

$\mathrm{Cu}(\mathrm{II})-\mathrm{A} \beta_{40}$

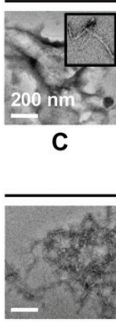

C

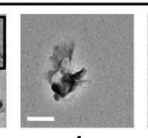

1

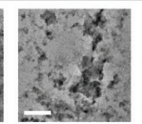

1

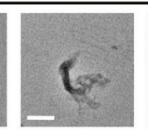

2 $\mathrm{Zn}(\mathrm{III})-\mathrm{A} \beta_{40}$

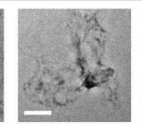

2

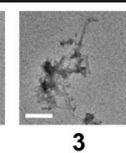

3

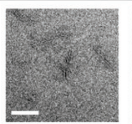

3

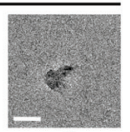

4

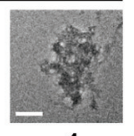

4
C: $\mathrm{A} \beta \pm\left[\mathrm{CuCl}_{2}\right.$ or $\left.\mathrm{ZnCl}_{2}\right]$

1: $A \beta \pm\left[\mathrm{CuCl}_{2}\right.$ or $\left.\mathrm{ZnCl}_{2}\right]+$ Morin

2: $\mathrm{A} \equiv \pm\left[\mathrm{CuCl}_{2}\right.$ or $\left.\mathrm{ZnCl}_{2}\right]+$ Quercetin

3: $\mathrm{A} \equiv \pm\left[\mathrm{CuCl}_{2}\right.$ or $\left.\mathrm{ZnCl}_{2}\right]+$ Galangin

4: $\mathrm{A} \beta \pm\left[\mathrm{CuCl}_{2}\right.$ or $\left.\mathrm{ZnCl}_{2}\right]+$ Luteolin

\begin{tabular}{|c|c|c|c|c|c|}
\hline \multirow{2}{*}{$\underset{\mathbf{A} \boldsymbol{\beta}_{40}}{\text { Fresh }} \pm$} & \multirow{2}{*}{$\begin{array}{c}\mathrm{CuCl}_{2} \\
\text { or } \\
\mathrm{ZnCl}_{2}\end{array}$} & $37^{\circ} \mathrm{C}, 24 \mathrm{~h}$ & \multirow{2}{*}{$\begin{array}{c}A \beta_{40} \\
\text { Aggregates }\end{array}$} & $\begin{array}{c}\text { Flavonoids } \\
24 \mathrm{~h} \\
\end{array}$ & \multirow{2}{*}{$\begin{array}{c}A \beta_{40} \\
\text { Species }\end{array}$} \\
\hline & & Agitation & & $37^{\circ} \mathrm{C}$, Agitation & \\
\hline
\end{tabular}
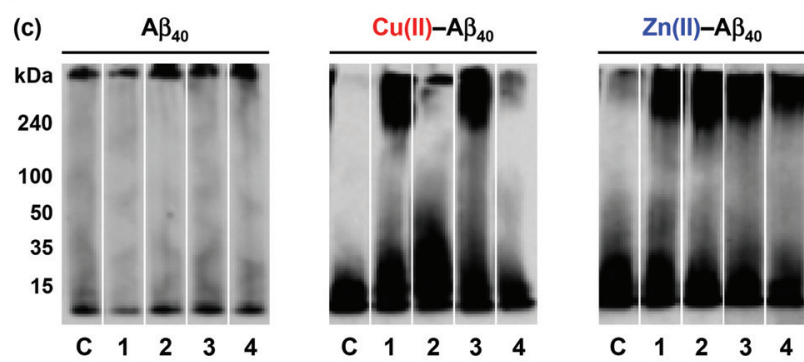

(d)

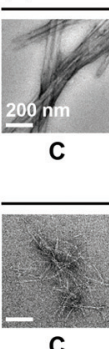

C
$\mathrm{Cu}(\mathrm{II})-\mathrm{A} \beta_{40}$

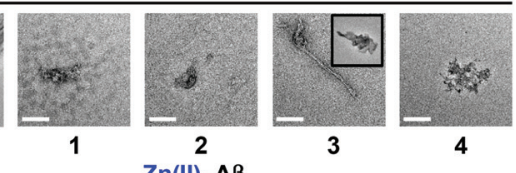

$\mathrm{Zn}(\mathrm{II})-\mathrm{A} \beta_{40}$
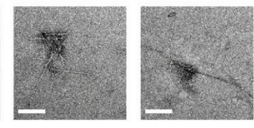

2
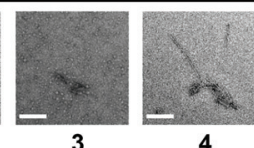

4

Fig. 2 Influence of the flavonoids on metal-free and metal-induced $A \beta_{40}$ aggregation. Top: schemes of inhibition (left) and disaggregation (right) experiments. For the inhibition experiment ( $a$ and $b$ ), $A \beta_{40}$ was first treated with or without $\mathrm{CuCl}_{2}$ or $\mathrm{ZnCl}$ followed by addition of flavonoids. The resulting samples were incubated at $37^{\circ} \mathrm{C}$ for $24 \mathrm{~h}$ with constant agitation. For the disaggregation experiment (c and d), $A \beta_{40}$ in the absence and presence of $\mathrm{CuCl}_{2}$ or $\mathrm{ZnCl}_{2}$ was initially incubated for $24 \mathrm{~h}$ with steady agitation. Flavonoids were then introduced into the resulting solution which was followed by an additional incubation for $24 \mathrm{~h}$ at $37^{\circ} \mathrm{C}$ with constant agitation. The resultant $A \beta_{40}$ species were visualized by gel/Western blot with an anti-A $\beta$ antibody (6E10) and TEM. Conditions: $\left[\mathrm{A} \beta_{40}\right]=25 \mu \mathrm{M}$; $\left[\mathrm{CuCl}_{2}\right.$ or $\left.\mathrm{ZnCl}_{2}\right]=25 \mu \mathrm{M}$; [flavonoids] = $50 \mu \mathrm{M}$; $\mathrm{pH} 6.6$ (for Cu(॥) experiments) or $\mathrm{pH} 7.4$ (for metal-free and $\mathrm{Zn}(\mathrm{II})$ experiments); $37^{\circ} \mathrm{C}$; $24 \mathrm{~h}$; constant agitation.

In both inhibition and disaggregation experiments, flavonoids might not be able to significantly modulate the aggregation pathways of both $A \beta_{40}$ and $A \beta_{42}$ under metal-free conditions (Fig. 2 and 3). Relatively similar molecular weight (MW) distributions of the resulting metal-free $A \beta$ species in both types of experiments with or without flavonoids were detected by gel/Western blot (Fig. 2 and 3). On the other hand, in both inhibition and disaggregation experiments, various size distributions were seen upon treatment of metal- $\mathrm{A} \beta$ with flavonoids to different extents (Fig. 2 and 3). From inhibition studies, the influence of flavonoids on the formation of diverse-sized metal- $\mathrm{A} \beta_{40}$ aggregates was indicative and visualized by gel/Western blot (Fig. 2a). Noticeably, as described in Fig. $2 \mathrm{a}$, the samples containing $\mathrm{Cu}(\mathrm{II})-\mathrm{A} \beta_{40}$ and flavonoids indicated more various-sized peptide species, compared to $\mathrm{Zn}(\mathrm{II})-\mathrm{A} \beta_{40}$ treated with flavonoids. In the case of $\mathrm{Zn}$ (II) $-\mathrm{A} \beta_{40}$, higher-sized $\mathrm{A} \beta_{40}$ species (above $100 \mathrm{kDa} \mathrm{MW}$ ) and smallersized $\mathrm{A} \beta_{40}$ species (lower than $50 \mathrm{kDa}$ ) were observed by gel/ Western blot (Fig. 2a). Moreover, upon treatment with flavonoids, smaller and more amorphous $\mathrm{Cu}(\mathrm{II})-\mathrm{A} \beta_{40}$ aggregates and less structured $\mathrm{Zn}(\mathrm{II})-\mathrm{A} \beta_{40}$ aggregates were monitored by TEM, relative to flavonoid-untreated metal-A $\beta$ samples (Fig. 2b).
Morin and quercetin, with the structures containing two hydroxyl groups on the $\mathrm{B}$ ring located apart from and close to each other, respectively, along with $3-\mathrm{OH}$ on the $\mathrm{C}$ ring, present noticeable redirection of metal- $\mathrm{A} \beta_{40}$ peptides into the off-pathway unstructured aggregates, suggested to be less toxic than well-structured $A \beta$ aggregates. ${ }^{15-17,26,30} \mathrm{~A}$ catechol moiety on the B ring with $3-\mathrm{OH}$ on the $\mathrm{C}$ ring (shown in quercetin, Fig. 1) may have influence on the modulation of metal- $A \beta_{40}$ $\left[\mathrm{Cu}(\mathrm{II})-\mathrm{A} \beta_{40}\right.$ and $\left.\mathrm{Zn}(\mathrm{II})-\mathrm{A} \beta_{40}\right]$ aggregation pathways more noticeably, compared to the structures with or without a catechol moiety on the $\mathrm{B}$ ring and a hydroxyl group on the $\mathrm{C}$ ring (shown in galangin or luteolin, Fig. 1). The only structural variation between quercetin and luteolin is the presence and absence of 3-OH, respectively, and this small substituent change can afford different oxidized form ${ }^{53-56}$ which could alter the interaction between flavonoids and metal- $\mathrm{A} \beta_{40}$ and modulation of metal- $\mathrm{A} \beta_{40}$ aggregation to different degrees. In addition, the 3-OH functionality, along with 4-oxo (Fig. 1), is suggested to be involved in metal chelation by quercetin $;^{33-36,56,57}$ its presence may help quercetin interact with metal-A $\beta$ species. Overall, metal-A $\beta_{40}$ aggregation could be controlled by treatment of the flavonoids to different 
$\mathrm{B}$ ring of the flavonoids, along with the $3-\mathrm{OH}$ group on the $\mathrm{C}$ ring, could direct the interactions with metal- $\mathrm{A} \beta_{42}$ species and subsequently control the peptide aggregation pathways more significantly.

Taken together, the overall gel/Western blot and TEM results demonstrate that the flavonoids (morin, quercetin, galangin, and luteolin; Fig. 1) could alter metal-induced A $\beta$ aggregation more noticeably over metal-free $A \beta$ analogue. The structural distinction, such as the number and position of hydroxyl groups on the $\mathrm{B}$ and $\mathrm{C}$ rings of a flavonoid backbone, as depicted in Fig. 1, could affect the ability of the flavonoids to redirect metal-A $\beta$ peptides into the off-pathway, unstructured peptide aggregates to different extents: (i) morin and quercetin containing hydroxyl groups on both $\mathrm{B}$ and $\mathrm{C}$ rings are observed to have such an activity significantly; (ii) galangin, which does not have a hydroxyl group on the $\mathrm{B}$ ring, may prefer to modulate metal-A $\beta_{40}$ aggregation over metal-A $\beta_{42}$ aggregation; (iii) luteolin, which has a catechol moiety on the $\mathrm{B}$ ring but does not have a 3-OH group on the $\mathrm{C}$ ring, could influence on metal-induced $A \beta_{40}$ and $A \beta_{42}$ aggregation pathways relatively less than morin and quercetin.

\section{Copper binding of morin, quercetin, galangin, and luteolin}

Since the selected flavonoids have shown a more noticeable ability to modulate $\mathrm{Cu}(\mathrm{II})-\mathrm{A} \beta_{40}$ aggregation over both metalfree $\mathrm{A} \beta_{40}$ and $\mathrm{Zn}$ (II)- $\mathrm{A} \beta_{40}$ aggregation, Cu(II) binding of flavonoids in both the absence and presence of $A \beta_{40}$ was investigated by UV-Visible (UV-Vis) spectroscopy (Fig. 4). As expected from the previously reported studies ( $\mathrm{O}$ donor atoms for metal binding), ${ }^{33-36,56,57}$ spectral changes were observed upon addition of $\mathrm{CuCl}_{2}$ into the solution containing flavonoids [20 mM HEPES, pH 7.4, $150 \mathrm{mM} \mathrm{NaCl].} \mathrm{Variations} \mathrm{in} \mathrm{optical}$ spectra, such as new optical bands and changes in absorbance intensity, were indicated. The intensity of absorption spectral changes and new optical bands were observed upon treatment of $\mathrm{CuCl}_{2}$ at ca. 325 and $410 \mathrm{~nm}$ (for morin), $448 \mathrm{~nm}$ (for quercetin), $417 \mathrm{~nm}$ (for galangin), and $413 \mathrm{~nm}$ (for luteolin) (Fig. 4a). These spectral changes were similar to previous metal binding studies, indicating the potential involvement of hydroxyl groups on the $\mathrm{B}$ and $\mathrm{C}$ rings in $\mathrm{Cu}$ (II) binding. ${ }^{33-36,56,57}$ Based on the previous studies, the groups of 3-OH/4-oxo, 5-OH/4-oxo, or a catechol (Fig. 1) have been proposed as metal chelation sites. ${ }^{36,56,57}$

In addition, $\mathrm{Cu}(\mathrm{II})$ binding of these flavonoids in the presence of $\mathrm{A} \beta_{40}$, which could help understand their reactivity toward $\mathrm{Cu}(\mathrm{II})-\mathrm{A} \beta$ aggregation, was studied by UV-Vis. To determine if the flavonoids could interact with $\mathrm{Cu}$ (II) surrounded by $\mathrm{A} \beta_{40}$, the compounds were introduced to the solution containing $\mathrm{A} \beta_{40}$ pre-treated with $\mathrm{Cu}(\mathrm{II})$. After morin, quercetin, galangin, and luteolin were added to $\mathrm{Cu}(\mathrm{II})-\mathrm{A} \beta_{40}[\mathrm{Cu}(\mathrm{II}): \mathrm{A} \beta$ : flavonoids, 1:1:1], optical spectra (Fig. 4b) were obtained, indicative of $\mathrm{Cu}(\mathrm{II})$ binding but were slightly different from those of $\mathrm{Cu}(\mathrm{II})$-ligand complexes [Cu(II): flavonoids, $1: 1]$ without $A \beta_{40}$ (Fig. 4a). Thus, from our UV-Vis experiments, it can be seen that morin, quercetin, galangin, and luteolin can interact with $\mathrm{Cu}(\mathrm{II})$ in both the absence and presence of $\mathrm{A} \beta$ to different degrees. Note that the binding properties (i.e., binding affinity and stoichiometry) of the flavonoids with $\mathrm{Cu}$ (II) or $\mathrm{Cu}$ (II)-bound $\mathrm{A} \beta$ explained in this work in detail were not able to be measured following previously reported
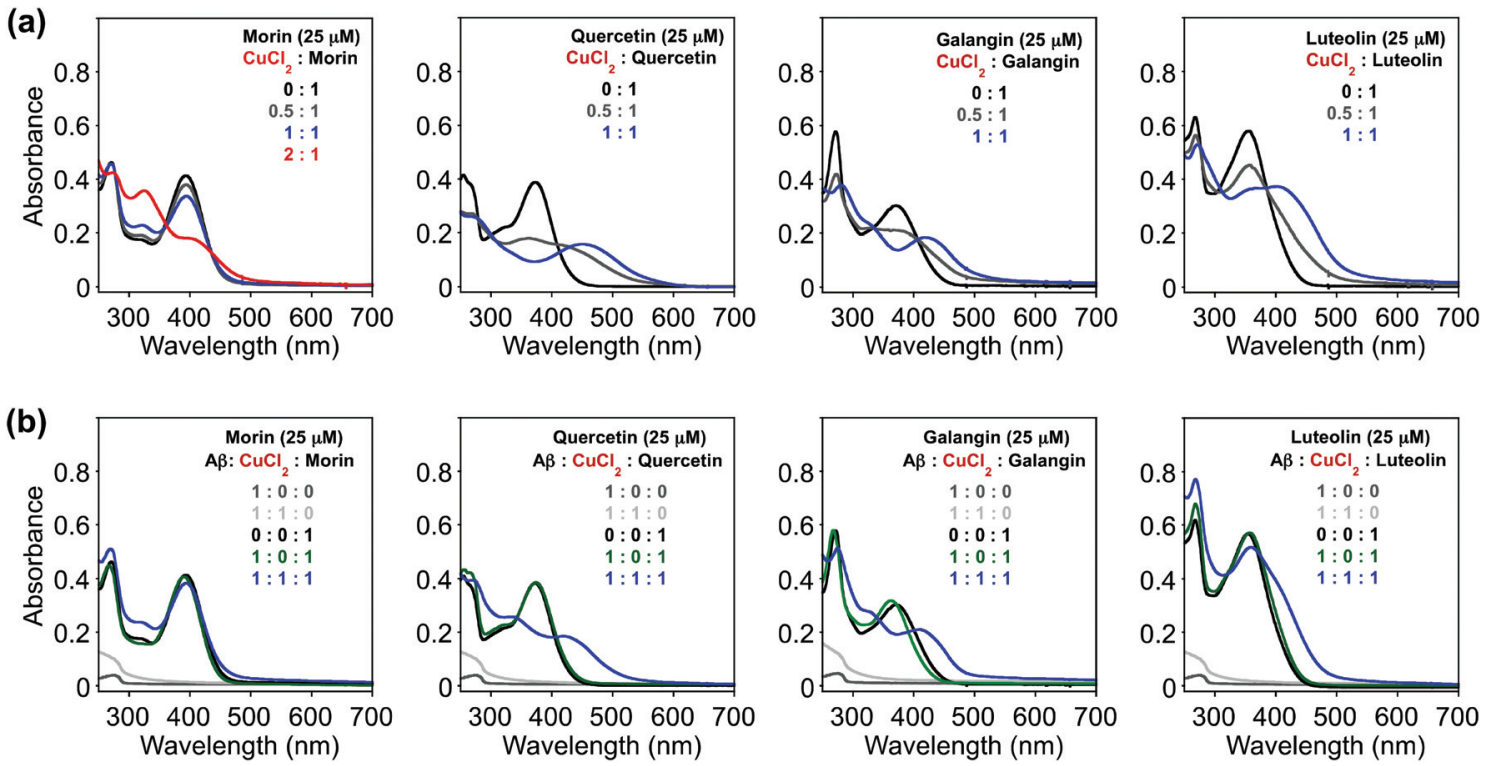

Fig. $4 \mathrm{Cu}(I)$ interaction of the flavonoids in both the absence and presence of $A \beta_{40}$, monitored by UV-Vis. (a) Optical spectra of the flavonoids in the absence (black) and presence (gray, blue, and red) of $\mathrm{Cu}\left(\right.$ (I) without $\mathrm{A} \beta_{40}$. (b) Optical spectra of the samples containing $\mathrm{A} \beta_{40}$, one equiv. of $\mathrm{CuCl}{ }_{2}$, and/or selected flavonoids. A solution containing $A \beta$ (dark gray) was treated with $\mathrm{CuCl}_{2}$ for 2 min (light gray) followed by flavonoids (blue). The spectra of flavonoids are presented in black. Conditions: $\left[\mathrm{A}_{40}\right]=25 \mu \mathrm{M} ;\left[\mathrm{CuCl}_{2}\right]=12.5-25$ (quercetin, galangin, and luteolin) or 12.5-50 (morin) $\mu \mathrm{M}$; [flavonoids] $=25 \mu \mathrm{M} ; 20 \mathrm{mM} \mathrm{HEPES}, \mathrm{pH} 7.4,150 \mathrm{mM} \mathrm{NaCl}$; room temperature; $10 \mathrm{~min}$. 

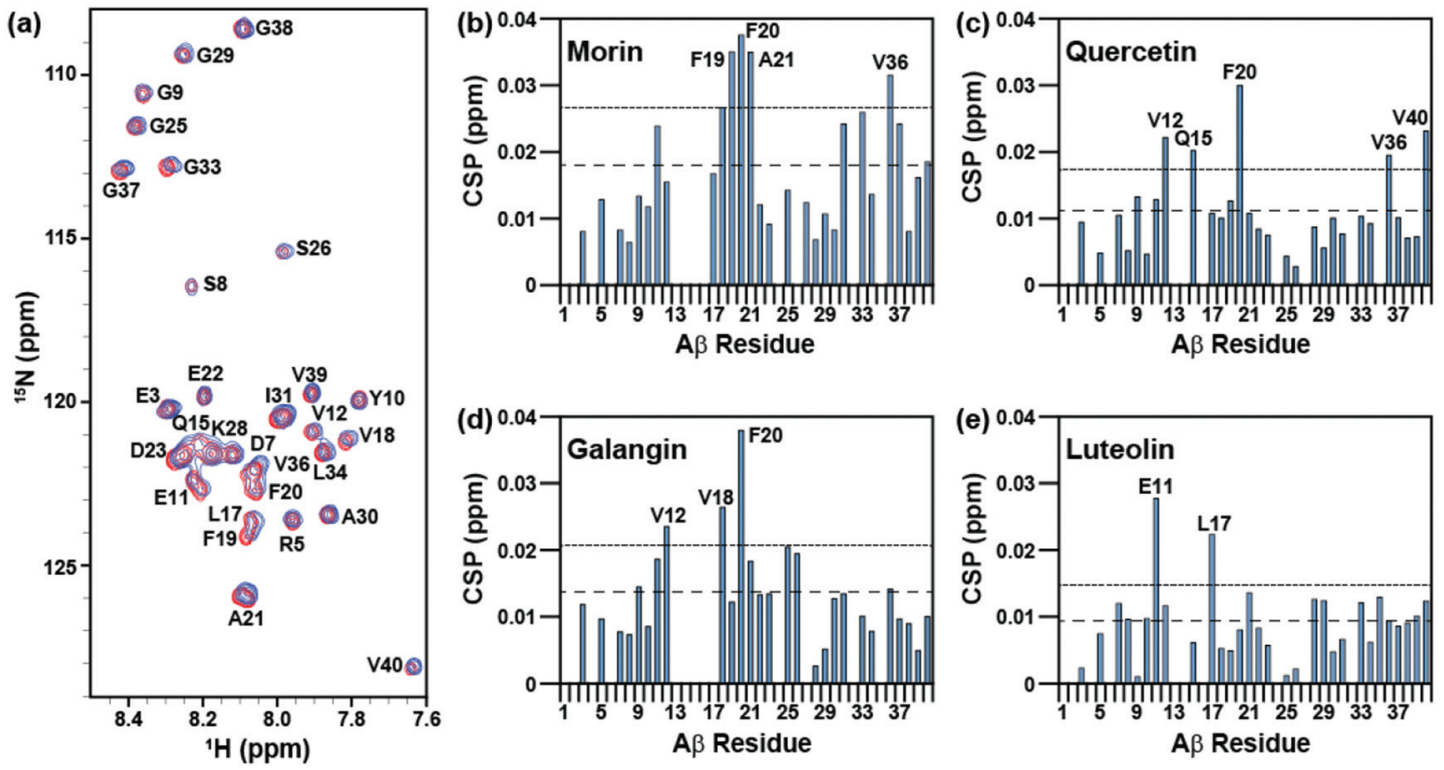

Fig. $5 \mathrm{~A} \beta$ interaction of the flavonoids, monitored by 2D SOFAST-HMQC NMR. NMR spectra were recorded as (a) morin was titrated into a solution of ${ }^{15} \mathrm{~N}$-labeled $\mathrm{A} \beta_{40}$ from 0 (red spectra) and 10 (blue spectra) equiv. of the flavonoids. The chemical shift perturbation (CSP) was calculated for each residue upon the titration of (b) morin, (c) quercetin, (d) galangin, and (e) luteolin in order to investigate their potential interaction with A $\beta$. The average chemical shift (dashed line) plus standard deviation (dotted line) were plotted for the reference. CSP values which exceed the sum of the average CSP and the standard deviation are indicative of noticeable interactions. Conditions: $\left[\mathrm{A} \beta_{40}\right]=80 \mu \mathrm{M} ;[\mathrm{flavonoids}]=0-800 \mu \mathrm{M} ; 20 \mathrm{mM}$ PO $\mathrm{pH} 7.4,50 \mathrm{mM} \mathrm{NaCl} ; 7 \% \mathrm{D}_{2} \mathrm{O}(\mathrm{v} / \mathrm{v}) ; 10^{\circ} \mathrm{C}$.

methods ${ }^{58}$ due to their instability especially in the presence of $\mathrm{Cu}(\mathrm{II})$.

\section{Interaction of flavonoids with soluble $\mathbf{A} \beta$ species}

The interaction of morin, quercetin, galangin, and luteolin with $A \beta_{40}$ was investigated with $2 \mathrm{D}$ band-Selective Optimized Flip-Angle Short Transient Heteronuclear Multiple Quantum Correlation (SOFAST-HMQC) NMR. ${ }^{41}$ Previously, this has been applied to identify which chemical alterations to a framework can direct the binding of a ligand to $A \beta_{40}$ and can elucidate the structural basis for distinct reactivity. ${ }^{22,23,25,26}$ The chemical shift perturbation (CSP) induced by the addition of flavonoids to the peptide was monitored to determine potentially preferred binding modes (Fig. 5 and S1 in the ESI $\dagger$ ).

All four flavonoids caused modest $(0.02-0.04 \mathrm{ppm})$ chemical shifts in different regions of the $A \beta_{40}$ sequence. Among them, morin induced the largest chemical shifts of amino acid residues in $\mathrm{A} \beta_{40}$ and may primarily target the residues within the self-recognition site (residues from F19 to A21) while also changing the environment around V36 in the C-terminal hydrophobic region (Fig. 5a and b)..$^{3-8}$ Quercetin relatively noticeably interacts with F20 at the self-recognition site in the peptide, ${ }^{3-8}$ as well as with V12 and Q15 which form a groove between the $3_{10}$-helix and the $\mathrm{N}$-terminus tail ${ }^{42}$ (Fig. 5c). Galangin may be able to interact with V18 and F20 from the self-recognition region ${ }^{3-8}$ and with V12 (Fig. 5d). Luteolin, which lacks 3-OH, preferentially perturbs E11 and L17 above all other residues (Fig. 5e). Furthermore, morin, quercetin, and galangin, which have 3-OH, impact F20 more noticeably than any other residues in $A \beta_{40}$, suggesting that the presence of 3-OH may promote the interaction of the flavonoid framework with F20 in the self-recognition region of the peptide. Although these three flavonoids could target F20, their other perturbed residues differ; thus, the position of the hydroxyl groups on the $\mathrm{B}$ ring also may have an effect on the interaction between $A \beta_{40}$ and flavonoids outside of the conserved interaction with F20. This implies that the flavonoids showing small different substitution patterns around the B ring interact with soluble $A \beta_{40}$ in a slightly different manner. Taken together, our NMR studies suggest that the variations of hydroxyl groups on both $\mathrm{B}$ and $\mathrm{C}$ rings could vary the interaction of flavonoids toward $A \beta_{40}$ peptides.

\section{Direct binding properties of flavonoids to $\mathrm{A} \beta$ species and conformational changes}

The interactions between monomeric or dimeric $\mathrm{A} \beta_{40}$ species and the flavonoids studied herein were further monitored in the absence and presence of $\mathrm{Cu}$ (II) by nano-electrospray mass spectrometry (nESI-MS) combined with IM-MS, optimized for the detection of non-covalent protein complexes. ${ }^{47,59-61}$ Data presented in Fig. 6 and S2 in the ESI $\dagger$ indicate that both quercetin and luteolin are capable of binding $A \beta_{40}$ in the absence of any metal ions. Contrary to expectations, monomeric $A \beta_{40}$ binding to quercetin and luteolin was only observed for the $3^{+}$ charge state, highlighting the weak binding of these molecules to the peptide. Expanding our analyses to incorporate the $A \beta_{40}$ dimer (Fig. S3 in the ESI $\dagger$ ), the results reveal that morin is shown to interact with metal-free $A \beta_{40}$, pointing to a likely 

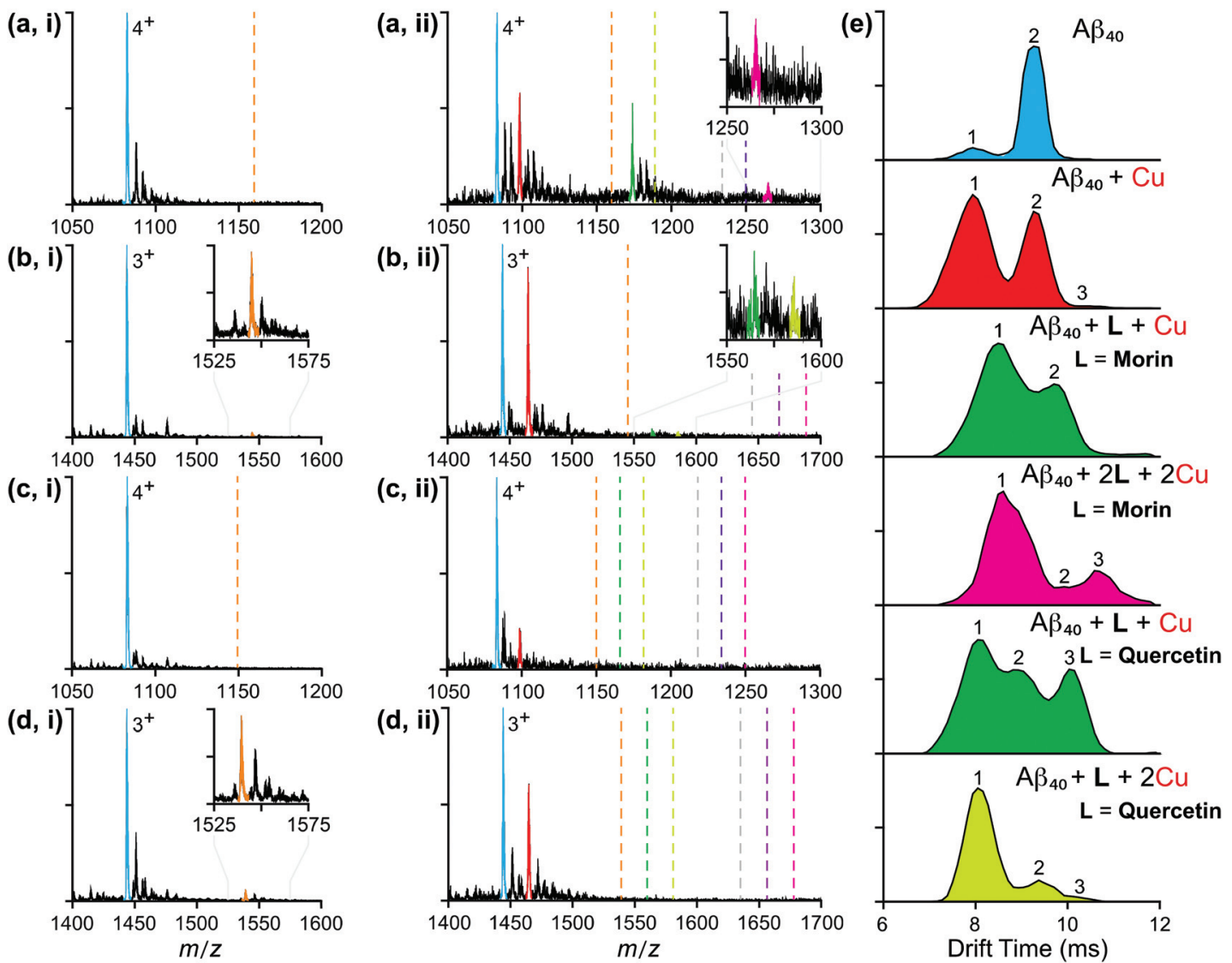

$A \beta_{40}:=A \beta_{40}+C u:=A \beta_{40}+L:=A \beta_{40}+2 L:=$

$A \beta_{40}+L+C u:=A \beta_{40}+L+2 C u:=A \beta_{40}+2 L+C u:=A \beta_{40}+2 L+2 C u:=$

Fig. 6 Mass spectrometric analysis of flavonoid-bound $A \beta_{40}$ monomers in both the absence and presence of $\mathrm{Cu}(\mathrm{II})$. Analysis of monomeric $A \beta_{40}$ $(20 \mu \mathrm{M})$ independently incubated with $120 \mu \mathrm{M}$ of either (a) morin, (b) quercetin, (c) galangin, or (d) luteolin in the (i) absence and (ii) presence of a source of $\mathrm{Cu}$ (II) (copper(II) acetate). Charge states are those that best represent the dominant ligand-bound species observed. Dashed lines represent the expected binding locations of the noted species based on theoretical average $\mathrm{m} / \mathrm{z}$ values. (e) lon mobility arrival times extracted from the full width half maximum (FWHM) of the observed $4^{+}$morin- and quercetin-bound $A \beta_{40}$ species. Calculated collision cross section values for these data are summarized in Table S2 in the ESI. $\dagger$

binding site comprised of a surface only presented in oligomeric A $\beta$. The analyses of dissociation constants $\left(K_{\mathrm{d}}\right.$; Table S1 in the ESI $\dagger$ ) for all metal-free data sets indicate that this oligomeric binding surface results in complex generation between $\mathrm{A} \beta$ and morin, quercetin, or luteolin; however, their binding with a metal-free $A \beta$ monomers and dimers is relatively weak $\left(K_{\mathrm{d}} \geq 400 \mu \mathrm{M}\right)$. The absence of any observable $\mathrm{A} \beta$-galangin complexes in our data suggests the lack of interactions between this flavonoid and the soluble $A \beta$ monomers or higher-order oligomers, and may suggest that the interaction of the flavonoid with oligomers is too large or too transient for IM-MS detection.

In order to investigate the ability of these flavonoids to redirect metal-induced $\mathrm{A} \beta$ aggregation in more detail, we performed MS experiments on $\mathrm{A} \beta$ complexes incubated in the presence of $\mathrm{Cu}$ (II) (Fig. 6). Interestingly, our data support that each sequential copy of morin bound to $A \beta_{40}$ requires a stoichiometric equivalent of $\mathrm{Cu}(\mathrm{II})$. These observations, when compared to our metal-free analyses, highlight the metal dependence of $A \beta$-morin binding. Quercetin, in contrast, is not shown to have such stoichiometric dependencies. Consistent with other data presented here, our results support the greater ability of morin and quercetin to target metal-bound $\mathrm{A} \beta_{40}$ than luteolin and galangin. Note that, while the analysis of flavonoid binding to $\mathrm{Cu}(\mathrm{II})$-bound $\mathrm{A} \beta_{40}$ dimers was attempted, data proved to be inconclusive due to poor signalto-noise levels associated with increased metal adduct formation and $A \beta$ aggregation states. To gain further insight into the structures of the flavonoid-A $\beta_{40}$ complexes observed here, we applied IM-MS in order to capture the size distributions of metal-A $\beta$-flavonoid complexes discussed above. Data for all observed, $4^{+}$ligated monomeric $\mathrm{A} \beta_{40}$ species are presented in Fig. 6e with CCS data (Table S2 in the ESI $\dagger$ ). Our overall IM-MS results indicate, in all instances, that flavonoid binding leads to the formation of conformationally distinct species compared to the metal-free/-bound states. As such, these results 


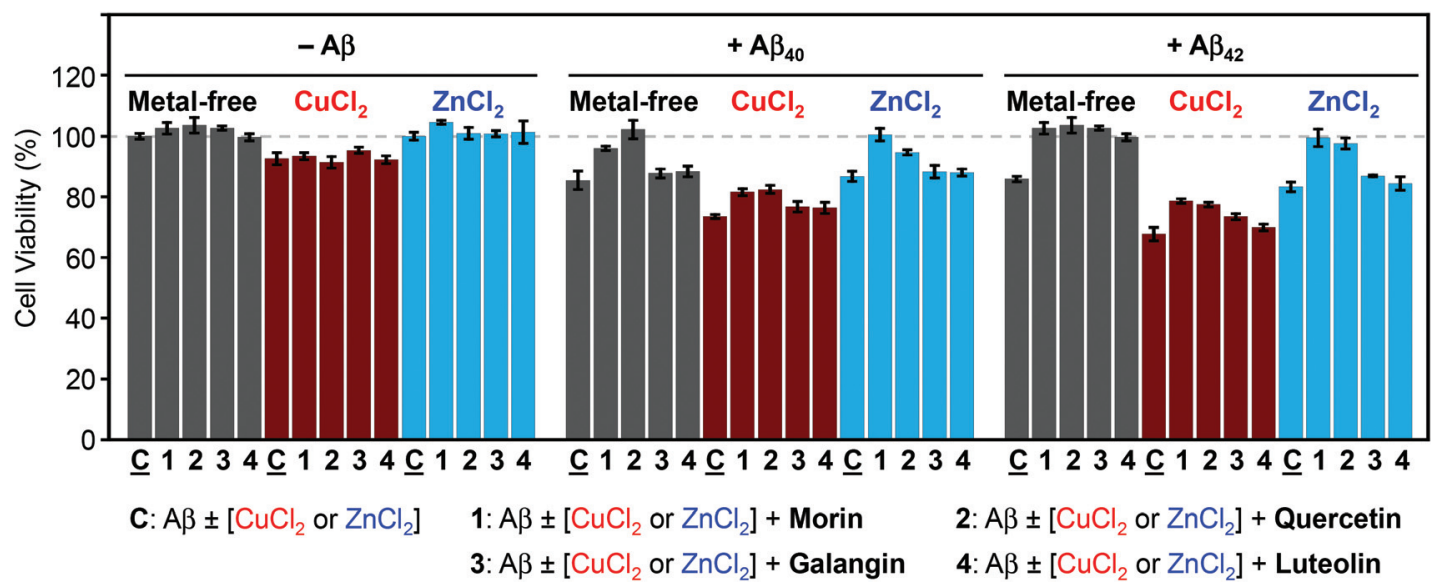

Fig. 7 Cell viability of the flavonoids with or without metal ions in both the absence and presence of $A \beta_{40}$ and $A \beta_{42}$. Cytotoxicity was measured by the MTT assay after $24 \mathrm{~h}$ of incubation of SH-SY5Y cells with and without A , a metal chloride salt $\left(\mathrm{CuCl}_{2}\right.$ or $\left.\mathrm{ZnCl}_{2}\right)$, or the selected flavonoids. The cell viability (\%) was calculated compared to cells treated with equivalent amounts of $\mathrm{DMSO}$ only $(0-1 \%, \mathrm{v} / \mathrm{v})$. Conditions: $[\mathrm{A} \beta]=10 \mu \mathrm{M}$; [CuCl 2 or $\mathrm{ZnCl}_{2}$ ] $=10 \mu \mathrm{M}$; [flavonoids] = $10 \mu \mathrm{M}$. Values represent the mean of four independent experiments ( \pm standard error).

are consistent with other IM-MS results for small molecules, previously reported to regulate $A \beta$ aggregation pathways. ${ }^{16,26}$

Regulation of toxicity induced by metal-free $A \beta$ and metal-A $\beta$ by morin, quercetin, galangin, and luteolin in living cells

The ability of morin, quercetin, galangin, and luteolin to recover toxicity induced by metal-free $\mathrm{A} \beta$ and metal-A $\beta$ was investigated in human neuroblastoma SH-SY5Y (5Y) cells. The cytotoxicity was determined by the MTT assay following previously published methods. ${ }^{21-24,26,27} 5 \mathrm{Y}$ cells were incubated with metal ions $(10 \mu \mathrm{M})$ and flavonoids $(10 \mu \mathrm{M})$ in the absence and presence of $\mathrm{A} \beta_{40}$ or $\mathrm{A} \beta_{42}(10 \mu \mathrm{M})$ for $24 \mathrm{~h}$.

As presented in Fig. 7 , in the absence of $A \beta$, flavonoids may not significantly affect cell viability with and without metal ions. When $A \beta_{40}$ or $A \beta_{42}$ was introduced to $5 \mathrm{Y}$ cells, it presented cell survival by $85( \pm 3) \%$ and $86( \pm 1) \%$, respectively. Moreover, cells treated with $\mathrm{A} \beta_{40}$ and $\mathrm{A} \beta_{42}$, along with $\mathrm{Cu}(\mathrm{II})$, exhibited lower viability $[73( \pm 1) \%$ and $68( \pm 2) \%]$, respectively (Fig. 7). When $A \beta_{40}$ and $A \beta_{42}$ were added to cells with $\mathrm{Zn}$ (II) they showed similar cell survival $[87( \pm 2) \%$ and $83( \pm 2) \%$, respectively] to metal-free $A \beta$-treated cells (Fig. 7). Both morin and quercetin could reduce the toxicity induced by metal-A $\beta$ by more than 10-20\% while galangin and luteolin could recover very slightly the cell viability by $c a$. $3-5 \%$ from the toxicity induced by metal-A $\beta$ (Fig. 7). These results may be related to their ability to redirect metal-A $\beta$ aggregation pathways to less toxic pathways, in addition to other properties of flavonoids, such as the anti-oxidant activity and interactions with other proteins. ${ }^{29,62-64}$ As presented above (vide supra), morin and quercetin, which have a hydroxyl group on both $\mathrm{B}$ and $\mathrm{C}$ rings (possibly essential for modulation of $A \beta$ aggregation and anti-oxidant properties ${ }^{63}$ ), may be able to alleviate the toxicity triggered by metal-free $A \beta$ and metal- $A \beta$ in living cells more significantly than galangin and luteolin.

\section{Conclusions}

Four flavonoids (morin, quercetin, galangin, and luteolin) were rationally selected based on variations of hydroxyl groups on their basic framework for investigating a structure-interaction-reactivity relationship toward metal-free $\mathrm{A} \beta$ and metal$\mathrm{A} \beta$. These flavonoids are shown to modulate metal-A $\beta_{40}$ and metal- $A \beta_{42}$ aggregation more noticeably than metal-free $A \beta_{40}$ and $A \beta_{42}$ analogue to different extents. The flavonoids with hydroxyl groups on both $\mathrm{B}$ and $\mathrm{C}$ rings (morin and quercetin) are indicated to significantly present their reactivity toward metal-A $\beta$, along with metal binding properties. Furthermore, these two flavonoids could distinguishably attenuate toxicity induced by metal-A $\beta$ in living cells. On the other hand, the flavonoids with a lack of hydroxyl groups on the $\mathrm{B}$ or $\mathrm{C}$ ring (galangin or luteolin) are shown to have less reactivity toward metal-A $\beta$ species. Such different reactivity of the flavonoids toward metal-free $\mathrm{A} \beta$ or metal-A $\beta$ is observed by biophysical approaches to be directed by distinct interactions with metal ions, metal-free $\mathrm{A} \beta$, and metal- $\mathrm{A} \beta$, which are mainly due to structural differences (i.e., number and position of hydroxyl groups on a flavonoid backbone). Our biophysical data indicate weak interactions of these flavonoids with metal-free $A \beta$ monomers and dimers to different degrees. Given the low affinity for metal-free $\mathrm{A} \beta$ binding, it is expected that a significant effect on metal-free $A \beta$ aggregation is not observed in our inhibition and disaggregation studies using a relatively low concentration of the flavonoids when compared to the $2 \mathrm{D}$ NMR and IM-MS datasets. Toward targeting and interacting with metal-bound $A \beta_{40}$, morin and quercetin are shown to have a greater ability than luteolin and galangin. Moreover, upon binding with morin and quercetin, the formation of conformationally distinct peptide species occurs compared to the metal-free/-bound peptide states untreated with the flavonoids. Taken together, our studies demonstrate a structure- 
interaction-reactivity relationship between the flavonoids and metal-free $A \beta$ or metal-A $\beta$. Variations of hydroxyl groups on the $\mathrm{B}$ and $\mathrm{C}$ rings of the flavonoids (structure) could tune their interactions with metal ions, metal-free $\mathrm{A} \beta$, and metal-A $\beta$ (interaction), which could subsequently govern their abilities to modulate metal-free $\mathrm{A} \beta$ or metal-A $\beta$ aggregation pathways and recover cytotoxicity induced by metal-free $A \beta$ and metal-treated A $\beta$ (reactivity). Moving forward, the knowledge presented in this work could advance our establishment of structural rationales toward the new development of chemical tools utilized for studying potential pathological factors, such as metalassociated amyloidogenic peptides and proteins, in human neurodegenerative disorders.

\section{Acknowledgements}

This work was supported by the National Research Foundation of Korea (NRF) Grant funded by the Korean Government [(MSIP) NRF-2014R1A2A2A01004877 to M. H. L.; NRF-2014S1A2A2028270 to M. H. L. and A. R.]; the 2015 Research Fund (Project Number 1.140101.01) of Ulsan National Institute of Science and Technology (UNIST) and the DGIST R\&D Program of the Ministry of Science, ICT and Future Planning of Korea (15-BD-0403) (to M. H. L.); the University of Michigan Protein Folding Disease Initiative (to B. T. R., A. R. and M. H. L.). This research was supported by the Global Ph.D. fellowship program through the National Research Foundation of Korea (NRF) funded by the Ministry of Education (NRF-2015HIA2A1030823) (to J. K.). R. A. K. thanks Dr. Molly Soper for her help in performing the gas phase $K_{\mathrm{d}}$ calculations.

\section{References}

1 Alzheimer's Association, Alzheimer's Dementia, 2015, 11, 332.

2 E. L. Que, D. W. Domaille and C. J. Chang, Chem. Rev., 2008, 108, 1517.

3 K. P. Kepp, Chem. Rev., 2012, 112, 5193.

4 R. Jakob-Roetne and H. Jacobsen, Angew. Chem., Int. Ed., 2009, 48, 3030.

5 M. G. Savelieff, S. Lee, Y. Liu and M. H. Lim, ACS Chem. Biol., 2013, 8, 856.

6 J. S. Derrick and M. H. Lim, ChemBioChem, 2015, 16, 887.

7 A. S. DeToma, S. Salamekh, A. Ramamoorthy and M. H. Lim, Chem. Soc. Rev., 2012, 41, 608.

8 A. S. Pithadia and M. H. Lim, Curr. Opin. Chem. Biol., 2012, 16, 67.

9 H. J. Lee, K. J. Korshavn, A. Kochi, J. S. Derrick and M. H. Lim, Chem. Soc. Rev., 2014, 43, 6672.

10 P. Faller, ChemBioChem, 2009, 10, 2837.

11 C. Rodriguez-Rodriguez, M. Telpoukhovskaia and C. Orvig, Coord. Chem. Rev., 2012, 256, 2308.

12 T. Hartmann, J. Kuchenbecker and M. O. W. Grimm, J. Neurochem., 2007, 103(Suppl 1), 159.
13 C. Hureau, Coord. Chem. Rev., 2012, 256, 2164.

14 M. A. Telpoukhovskaia and C. Orvig, Chem. Soc. Rev., 2013, 42, 1836.

15 M. G. Savelieff, A. S. DeToma, J. S. Derrick and M. H. Lim, Acc. Chem. Res., 2014, 47, 2475.

16 M. W. Beck, S. B. Oh, R. A. Kerr, H. J. Lee, S. H. Kim, S. Kim, M. Jang, B. T. Ruotolo, J.-Y. Lee and M. H. Lim, Chem. Sci., 2015, 6, 1879.

17 S. Lee, X. Zheng, J. Krishnamoorthy, M. G. Savelieff, H. M. Park, J. R. Brender, J. H. Kim, J. S. Derrick, A. Kochi, H. J. Lee, C. Kim, A. Ramamoorthy, M. T. Bowers and M. H. Lim, J. Am. Chem. Soc., 2014, 136, 299.

18 M. G. Savelieff, Y. Liu, R. R. P. Senthamarai, K. J. Korshavn, H. J. Lee, A. Ramamoorthy and M. H. Lim, Chem. Commun., 2014, 50, 5301.

19 A. S. Pithadia, A. Kochi, M. T. Soper, M. W. Beck, Y. Liu, S. Lee, A. S. DeToma, B. T. Ruotolo and M. H. Lim, Inorg. Chem., 2012, 51, 12959.

20 J.-S. Choi, J. J. Braymer, S. K. Park, S. Mustafa, J. Chae and M. H. Lim, Metallomics, 2011, 3, 284.

21 J. J. Braymer, J.-S. Choi, A. S. DeToma, C. Wang, K. Nam, J. W. Kampf, A. Ramamoorthy and M. H. Lim, Inorg. Chem., 2011, 50, 10724.

22 J.-S. Choi, J. J. Braymer, R. P. R. Nanga, A. Ramamoorthy and M. H. Lim, Proc. Natl. Acad. Sci. U. S. A., 2010, 107, 21990.

23 S. S. Hindo, A. M. Mancino, J. J. Braymer, Y. Liu, S. Vivekanandan, A. Ramamoorthy and M. H. Lim, J. Am. Chem. Soc., 2009, 131, 16663.

24 A. Kochi, H. J. Lee, S. M. Vithanarachchi, V. Padmini, M. J. Allen and M. H. Lim, Curr. Alzheimer Res., 2015, 12, 415.

25 A. S. DeToma, J. Krishnamoorthy, Y. Nam, H. J. Lee, J. R. Brender, A. Kochi, D. Lee, V. Onnis, C. Congiu, S. Manfredini, S. Vertuani, G. Balboni, A. Ramamoorthy and M. H. Lim, Chem. Sci., 2014, 5, 4851.

26 S.-J. Hyung, A. S. DeToma, J. R. Brender, S. Lee, S. Vivekanandan, A. Kochi, J.-S. Choi, A. Ramamoorthy, B. T. Ruotolo and M. H. Lim, Proc. Natl. Acad. Sci. U. S. A., 2013, 110, 3743.

27 A. S. DeToma, J.-S. Choi, J. J. Braymer and M. H. Lim, ChemBioChem, 2011, 12, 1198.

28 F. I. Baptista, A. G. Henriques, A. M. S. Silva, J. Wiltfang and O. A. B. da Cruz e Silva, ACS Chem. Neurosci., 2014, 5, 83.

29 J. Kim, H. J. Lee and K. W. Lee, J. Neurochem., 2010, 112, 1415.

30 D. E. Ehrnhoefer, J. Bieschke, A. Boeddrich, M. Herbst, L. Masino, R. Lurz, S. Engemann, A. Pastore and E. E. Wanker, Nat. Struct. Mol. Biol., 2008, 15, 558.

31 T. Akaishi, T. Morimoto, M. Shibao, S. Watanabe, K. SakaiKato, N. Utsunomiya-Tate and K. Abe, Neurosci. Lett., 2008, 444, 280.

32 K. Ono, Y. Yoshiike, A. Takashima, K. Hasegawa, H. Naiki and M. Yamada, J. Neurochem., 2003, 87, 172.

33 Q. K. Panhwar, S. Memon and M. I. Bhanger, J. Mol. Struct., 2010, 967, 47. 
34 J. E. Brown, H. Khodr, R. C. Hider and C. A. Rice-Evans, Biochem. J., 1998, 330(Pt 3), 1173.

35 W. M. Tay, G. F. Z. da Silva and L. J. Ming, Inorg. Chem., 2013, 52, 679.

36 S. Cao, X. Jiang and J. Chen, J. Inorg. Biochem., 2010, 104, 146.

37 H. Ushikubo, S. Watanabe, Y. Tanimoto, K. Abe, A. Hiza, T. Ogawa, T. Asakawa, T. Kan and T. Akaishi, Neurosci. Lett., 2012, 513, 51.

38 R. Alvarez-Diduk, M. T. Ramírez-Silva, A. Galano and A. Merkocị, J. Phys. Chem. B, 2013, 117, 12347.

39 A. Bravo and J. R. Anacona, Transition Met. Chem., 2001, 26, 20.

40 M. Sato, K. Murakami, M. Uno, Y. Nakagawa, S. Katayama, K. Akagi, Y. Masuda, K. Takegoshi and K. Irie, J. Biol. Chem., 2013, 288, 23212.

41 P. Schanda and B. Brutscher, J. Am. Chem. Soc., 2005, 127, 8014.

42 S. Vivekanandan, J. R. Brender, S. Y. Lee and A. Ramamoorthy, Biochem. Biophys. Res. Commun., 2011, 411, 312.

43 S. I. Yoo, M. Yang, J. R. Brender, V. Subramanian, K. Sun, N. E. Joo, S.-H. Jeong, A. Ramamoorthy and N. A. Kotov, Angew. Chem., Int. Ed., 2011, 50, 5110.

44 N. L. Fawzi, J. Ying, D. A. Torchia and G. M. Clore, J. Am. Chem. Soc., 2010, 132, 9948.

45 K. Giles, J. P. Williams and I. Campuzano, Rapid Commun. Mass Spectrom., 2011, 25, 1559.

46 Y. Zhong, S.-J. Hyung and B. T. Ruotolo, Analyst, 2011, 136, 3534.

47 B. T. Ruotolo, J. L. P. Benesch, A. M. Sandercock, S.-J. Hyung and C. V. Robinson, Nat. Protoc., 2008, 3, 1139.

48 M. F. Bush, Z. Hall, K. Giles, J. Hoyes, C. V. Robinson and B. T. Ruotolo, Anal. Chem., 2010, 82, 9557.
49 M. T. Soper, A. S. DeToma, S.-J. Hyung, M. H. Lim and B. T. Ruotolo, Phys. Chem. Chem. Phys., 2013, 15, 8952.

50 W. Wang, E. N. Kitova and J. S. Klassen, Anal. Chem., 2003, 75, 4945.

51 S. L. Bernstein, N. F. Dupuis, N. D. Lazo, T. Wyttenbach, M. M. Condron, G. Bitan, D. B. Teplow, J.-E. Shea, B. T. Ruotolo, C. V. Robinson and M. T. Bowers, Nat. Chem., 2009, 1, 326.

52 S. V. Jovanovic, S. Steenken, M. Tosic, B. Marjanovic and M. G. Simic, J. Am. Chem. Soc., 1994, 116, 4846.

53 L. V. Jorgensen, C. Cornett, U. Justesen, L. H. Skibsted and L. O. Dragsted, Free Radical Res., 1998, 29, 339.

54 G. Galati, M. Y. Moridani, T. S. Chan and P. J. O'Brien, Free Radical Biol. Med., 2001, 30, 370.

55 S. V. Jovanovic, S. Steenken, Y. Hara and M. G. Simic, J. Chem. Soc., Perkin Trans. 2, 1996, 11, 2497.

56 A. Pekal, M. Biesaga and K. Pyrzynska, BioMetals, 2011, $24,41$.

57 M. D. Engelmann, R. Hutcheson and I. F. Cheng, J. Agric. Food Chem., 2005, 53, 2953.

58 J. Geng, M. Li, L. Wu, J. Ren and X. Qu, J. Med. Chem., 2012, 55, 9146.

59 H. Hernandez and C. V. Robinson, Nat. Protoc., 2007, 2, 715.

60 G. R. Hilton and J. L. P. Benesch, J. R. Soc., Interface, 2012, 9, 801.

61 L. M. Young, J. C. Saunders, R. A. Mahood, C. H. Revill, R. J. Foster, L. H. Tu, D. P. Raleigh, S. E. Radford and A. E. Ashcroft, Nat. Chem., 2015, 7, 73.

62 K. L. Wolfe and R. H. Liu, J. Agric. Food Chem., 2008, 56, 8404.

63 C. A. Rice-Evans, N. J. Miller, P. G. Bolwell, P. M. Bramley and J. B. Pridham, Free Radical Res., 1995, 22, 375.

64 P. G. Pietta, J. Nat. Prod., 2000, 63, 1035. 